\title{
MICRO EXTRACTION OF DNA FROM WHOLE BLOOD AND AMNIOCYTES
}

\author{
Tetsuya Hirota, ${ }^{1,2}$ Tatsuro KondoH, ${ }^{1,2}$ Tadashi Matsumoto, ${ }^{1}$ \\ Yoshihiro JINNO, ${ }^{1}$ and Norio NIIKAWA ${ }^{1}$ \\ ${ }^{1}$ Department of Human Genetics and ${ }^{2}$ Department of Pediatrics, \\ Nagasaki University School of Medicine, Nagasaki 852, Japan
}

\begin{abstract}
Summary We describe methods for extracting genomic DNA from a small amount of whole blood or cultured amniocytes. Nuclear DNA was extracted from whole blood spotted on blotting paper. Relatively large molecules of DNA with the average amount of 7-9 $\mu \mathrm{g}$ was extracted from $1 \mathrm{ml}$ of blood spotted and stored for at most two years, being roughly $1 / 3$ of that extracted directly from fresh whole blood. The estimated minimum amount of whole blood that gives a suitable autoradiogram of Southern hybridization was $0.3 \mathrm{ml}$. Another series of amounts of whole blood or an amniocyte suspension were molded in low-melting agarose into an $100 \mu \mathrm{l}$ gel block. The DNA extracted from a block that was made from at least $0.25 \mathrm{ml}$ of whole blood, or from $1.25 \times 10^{5}$ amniocytes (equivalent to $1 / 8$ of the number of confluent cells in a $25 \mathrm{~cm}^{2}$ culture flask) resulted in one suitable Southern analysis. Both methods described here are applicable to the diagnosis of newborns and/or fetuses at risk of a genetic disease and to the diagnosis of a patient from whom a large amount of blood material is difficult to obtain. These methods also make a long-way transportation of the materials possible.
\end{abstract}

Key Words micro DNA extraction, blotted blood method, gel-block method, DNA-based prenatal/neonatal diagnosis of genetic disease

\section{INTRODUCTION}

Neonatal and/or prenatal diagnosis of genetic diseases has become more important, because a number of the diseases can now be analyzed at the DNA level with the molecular-genetic techniques (Cooper and Schmidke, 1986; 1987). However, the amount of blood, as a source of DNA material, available in the newborn

Received June 7, 1989; revised version received June 26, 1989; Accepted July 4, 1989.

Address reprint requests to: Tetsuya Hirota, M.D., Department of Human Genetics, Nagasaki University School of Medicine, Sakamoto-machi, 12-4 Nagasaki 852, Japan. 
is limited and the extraction of DNA from the amniotic fluid cells usually requires a long-term culture to proliferate the amniocytes by the number of some $10^{6}-10^{7}$. Furthermore, because of a few institutions where the diagnosis with DNA techniques can be made, the materials are often required to be transported to an institution far away. A method for micro DNA-extraction from dried blood spots on filter paper blotters has thus been developed (McCabe et al., 1987) and has then applied to the diagnosis of sickle cell disease (Jinks et al., 1989).

We describe here two methods for DNA extraction from a small amount of whole blood or cultured amniocytes to apply to the neonatal or prenatal diagnosis.

\section{MATERIALS AND METHODS}

Blotted blood method. Whole blood taken from a healthy adult was used as a source of genomic DNA for further studies. Each $1 \mathrm{ml}$ of blood was spotted on Whatman 3MM paper (Whatman International Ltd.), Toyo No. 2 blotting paper (Toyo Roshi Co., Ltd., Tokyo), or on the blotting paper for the blood screening test of Guthrie. After drying and storing at room temperature or at $4{ }^{\circ} \mathrm{C}$ for one day to eight years, each sheet of blood spotted paper was immersed into 10 $\mathrm{ml}$ of $0.85 \% \mathrm{NaCl}$ solution in a plastic Petri dish with or without mincing, and was shaken gently for 3-4 hr to detach leukocytes. The mixture was collected in a plastic tube and centrifuged at $1,500 \mathrm{rpm}$ for $10 \mathrm{~min}$. The cell pellet was suspended in $500 \mu$ of SE solution ( $75 \mathrm{~mm} \mathrm{NaCl}, 5 \mathrm{~mm}$ EDTA, pH 8.0) to which 25 $\mu \mathrm{l}$ of $1 \mathrm{mg} / \mathrm{ml}$ proteinase $\mathrm{K}$ (Sigma Chemical Co.) and $50 \mu \mathrm{l}$ of $10 \%$ sodium dodecyl sulfate were added, and incubated at $37^{\circ} \mathrm{C}$ overnight. Then, DNA was extracted with the phenol-chloroform mixture by changing three times, dehydrated with buthanol and precipitated with ethanol. The precipitate was dissolved in $30 \mu \mathrm{l}$ of $1 \times \mathrm{TE}$ solution ( $10 \mathrm{~mm}$ Tris-Cl, $1 \mathrm{~mm}$ EDTA, pH 8.0).

Gel block method for blood. Leukocytes separated from whole blood were portioned at various concentrations: $7.5 \times 10^{5}, 1.25 \times 10^{6}, 2.5 \times 10^{6}, 3.75 \times 10^{6}$ and $5 \times 10^{6}$, which are equivalent to the number of leukocytes in $0.15,0.25,0.5,0.75$ and $1.0 \mathrm{ml}$ of whole blood, respectively. The gel block method described here was the modification of the previous method for pulsed field gradient electrophoresis (Georges and Maynard, 1984). Each portion of leukocytes was suspended in 50 $\mu \mathrm{l}$ of SE solution. The suspension was mixed with $50 \mu \mathrm{l}$ of prewarmed $1 \%$ lowmelting agarose gel (Bio-Rad Laboratories, Cat. No. 162-0017), and the mixture was immediately molded into a gel block sized $10 \times 2 \times 5 \mathrm{~mm}$. After the gel became solid, the block was put into five volume of ES solution (0.5 M EDTA, 1\% laurylsarcosinate) to which $30 \mu \mathrm{l}$ of $1 \mathrm{mg} / \mathrm{ml}$ proteinase $\mathrm{K}$ was added, and incubated at $55^{\circ} \mathrm{C}$ overnight in order to extract DNA directly from leukocyte nuclei in the block.

Gel block method for amniocytes. The cultured amniocytes $\left(1 \times 10^{6}\right.$ cells $/$ flask) were centrifuged at $1,000 \mathrm{rpm}$ for $6 \mathrm{~min}$, and the cells were suspended in 50 $\mu \mathrm{l}$ of SE solution to which another $50 \mu \mathrm{l}$ of $1 \%$ prewarmed low-melting agarose 
gel was added. From the amniocytes in each culture flask, two blocks $\left(5 \times 10^{5}\right.$ cells/block), 4 blocks $\left(2.5 \times 10^{5} /\right.$ block $)$, and 8 blocks $\left(1.25 \times 10^{5} /\right.$ block $)$ were made. The block was put into five volumes of ES solution containing $30 \mu$ of proteinase $\mathrm{K}$, and incubated at $55^{\circ} \mathrm{C}$ overnight.

Control DNA material. Genomic DNA was extracted with the standard method (Matsumoto et al., 1988) from $20 \mathrm{ml}$ of whole blood of a normal adult. The DNA was diluted and portioned at various concentrations corresponding to the number of cells in samples in each method described above.

Southern hybridization. DNA extracted with the blotted blood method was digested by 20 units (U) of the endonuclease HindIII at $37^{\circ} \mathrm{C}$ overnight, and the digests were put into the wells in $0.8 \%$ agarose gel. Gel block samples of whole blood were put into five volumes of ES solution $(0.5 \mathrm{M}$ EDTA, $1 \%$ lauryl sarcosinate, $\mathrm{pH} 8.0$ ) to. which 20,40 , or $80 \mathrm{U}$ of HindIII were added. Gel block samples of amniocytes were digested by $20 \mathrm{U}$ of the enzyme. After digestion, the blocks were inserted into the wells in $0.8 \%$ agarose gel. Further electrophoresis and the Soythern blotting were according to the standard methods (Southern, 1975; Maniatis et al., 1982). Five cloned DNAs, pERT87-1 (located at Xp21.2), pML34 and pTD3-21 (both located at 15q11-q12), pPA1 (located at 18q11.2-q12.1), and pC4s (located at $6 \mathrm{p} 21.1$ ), were ${ }^{32} \mathrm{P}-1$ abeled with the multiprime DNA labeling system (Amersham International plc., U.K.) and used as hybridization probes. Prehybridization, hybridization, washing and autoradiography were carried out according to the ordinary protocol as described previously (Matsumoto et al., 1988).

\section{RESULTS}

\section{Blotted blood method}

Each blood spot containing $1 \mathrm{ml}$ of blood on a sheet of blotting paper stored for one day to two years gave relatively large molecules of DNA with the amount of 7 to $9 \mu \mathrm{g}$ DNA which correspond to the amount suitable for one or two Southern hybridization analyses (Fig. 1A). There was no difference among the three kinds of paper in yield of DNA and in duration of preservation within 30 days. The yield of DNA with this method was about one-third of the direct yield from the corresponding amount of whole blood with the standard method. However, the quality of DNA from the blotted paper was fair because sometimes the DNA could not easily be digested by HindIII. The extraction of DNA from the blotting paper that was minced was insufficient. Blotted blood that was stored for three years or more gave only small molecules of DNA. The DNA-fragmentation tended to increase with the time of preservation (Fig. 2).

\section{Gel block method}

Every block with various concentrations of leukocytes gave the amount of DNA sufficient for one or several Southern blot analyses (Fig. 1B). Twenty units 


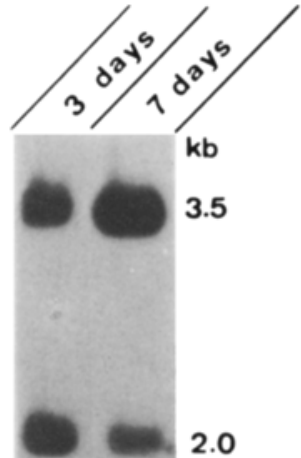

A

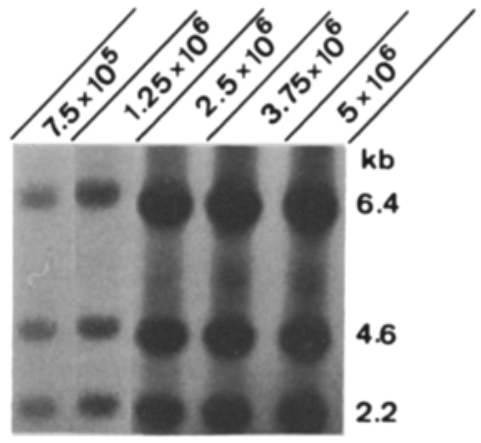

B

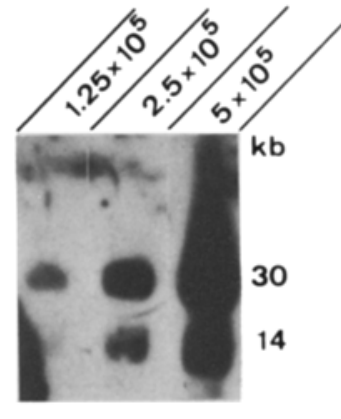

C

Fig. 1. Autoradiograms of DNA extracted from $1 \mathrm{ml}$ of blotted blood stored at room temperature for 3 days and for 7 days, both hybridized with pERT87-1 (A), and from various concentrations of leukocytes in gel blocks, hybridized with triple probes, pML34 (corresponding to $6.4 \mathrm{~kb}$ fragnent), pTD3-21 $(2.2 \mathrm{~kb})$ and pPA1 $(4.6 \mathrm{~kb})(\mathrm{B})$, and from amniocytes in gel blocks hybridized with pC4s (C).

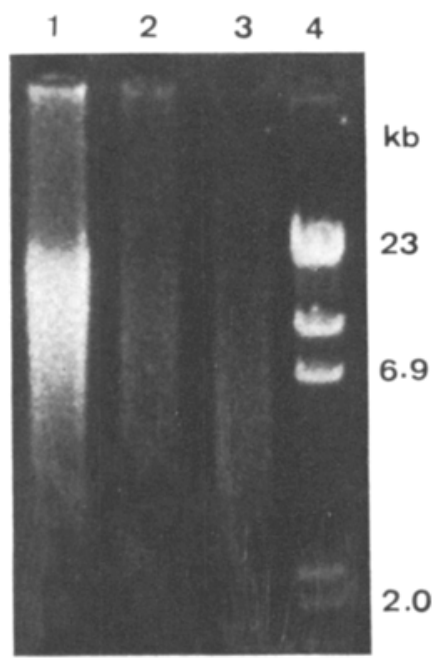

Fig. 2. Ethidium bromide stained DNA extracted from dried spotted blood that was long stored at room temperature. Lane 1, DNA from blood stored for one year; lane 2 , for three years; lane 3 , for eight years; lane 4 , size marker.

of HindIII were enough to digest DNA in a block made from $1 \mathrm{ml}$ of blood completely. The DNA fragments was detected in the sample prepared from at least $0.15 \mathrm{ml}$ of whole blood. However, for an accurate DNA analysis, $0.25 \mathrm{ml}$ of blood was required.

The DNA in the block containing $1.25 \times 10^{5}$ or $2.5 \times 10^{5}$ amniocytes could 


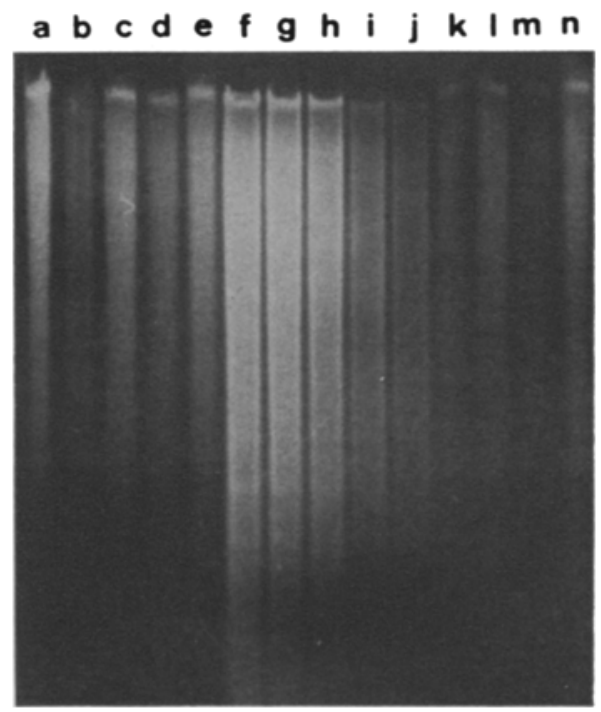

Fig. 3. Comparison of DNA concentrations in ethidium bromide-stained agarose gel between the gel block method and the standard method. Lanes a-e, DNA extracted from various concentrations of leukocytes with the gel block method; lanes $\mathrm{f}-\mathrm{j}, \mathrm{DNA}$ from leukocytes with the standard method; lanes $\mathrm{k}-\mathrm{n}, \mathrm{DNA}$ from amniocytes with the gel block method. Each DNA extracted with the standard method was the DNA diluted from the DNA pool which was totally extracted from $20 \mathrm{ml}$ of whole blood, according to the corresponding numbers of leukocytes, while the DNA obtained with the gel block method was the one extracted directly from cells which had been already portioned.

be digested completely by $20 \mathrm{U}$ of HindIII, and the DNA fragments could be detected as convincing autoradiograms, while the DNA from $5 \times 10^{5}$ amniocytes was incompletely digested by the same amount of the enzyme (Fig. 1C).

The quantity of DNA in the ethidium bromide-stained agarose gel after electrophoresis was compared between the gel block samples of leukocytes or aminocytes and the control DNA samples which were obtained directly from leukocytes with the standard method (Fig. 3). There was no big difference in quantity and quality of DNA between the two methods.

\section{DISCUSSION}

With the blotted blood method described here, the estimated minimum volume of whole blood, from which a sufficient amount of DNA for one Southern blot analysis might be extracted, was $0.3 \mathrm{ml}$, regardless of the kind of paper. This minimum volume of blood can easily be taken from a newborn with either a syringe or a heel-puncture. There was no relationship between the amount or quality of DNA and the duration of drying or the condition of preservation within two years. 
Since every pediatrician, obstetrician, midwife or nurse has much experience of dealing with a spotted-blood sheet of the Guthrie paper through the blood screening test, the method described is applicable to a future DNA-based screening for genetic diseases in the newborn. In addition, this method can also be applied to the individual identification in the field of forensic medicine, if combined with the DNA "fingerprints" method (Gill et al., 1985). On the other hand, there are some drawbacks of this DNA-extraction method. The problems include that the amount of DNA extracted from blood-spotted paper is not always constant, and that the amount of extracted DNA was about one-third of that obtained with the standard method. Our result is comparable to that of the previous study in which $0.5 \mu \mathrm{g}$ of DNA was extracted from the $50 \mu$ of spotted whole blood (McCabe et al., 1987). This problem is mainly due to insufficient detaching of leukocytes from the fibernet of the paper used. The simultaneous use of polymerase chain reaction technique (Li et al., 1988) to amplify the genomic DNA of a patient may overcome this problem. Another problem includes the limited preservation time. Spotted blood which had been stored three years and more gave only small molecules of DNA even if the blood was carefully handled throughout the procedures.

The gel block method described here provided a higher efficiency of DNA extraction than the standard method, especially when the number of cells available is few. The advantages of the gel block method are as follows: the ethanol precipitation step can be skipped; loss of DNA during the extraction steps may be negligible; and a long-term culture of amniocytes is unnecessary. Amniocentesis is usually performed at the 15th-20th gestational week, and the dead line for therapeutic abortion is decided at the end of the 24 th week by the law in Japan. Therefore, we can shorten the period between the amniocentesis and the DNA-based diagnosis with the use of the gel block method.

Both methods described here are applicable to the diagnosis of newborns and/ or fetuses at risk of a genetic disease and to the diagnosis of a patient from whom a large amount of blood material is difficult to take, and also make a long-way transportation of the material possible.

Acknowledgments We express our gratitude to Professor Ichiro Matsuda, Kumamoto University and to Dr. Hozo Umehashi, The Chemo-Sero-Therapeutic Research Institute, Kumamoto, for providing long-stored spotted blood.

This study was supported in part by a grant for "Prevention from Genetic Diseases" from Ministry of Health and Welfare of Japan.

\section{REFERENCES}

Cooper, D.N. and Schmidtke, J. 1986. Diagnosis of genetic disease using recombinant DNA. Hum. Genet. 73: 1-11.

Cooper, D.N. and Schmidtke, J. 1987. Diagnosis of genetic disease using recombinant DNA. Supplement. Hum. Genet. 77: 66-75.

Georges, F.C. and Maynard, V.O. 1984. Separation of chromosomal DNA molecules from yeast 
by orthogonal-field-alternation gel electrophoresis. Nucleic Acid Res. 12: 5647-5664.

Gill, P., Jeffreys, A.J. and Werrett, D.J. 1985. Forensic application of DNA "fingerprints." $\mathrm{Na}$ ture 318: $577-579$.

Jinks, D.C., Minter, M., Tarver, D.A., Vanderford, M., Hejtmancik, J.F. and McCabe, E.R.B. 1989. Molecular genetic diagnosis of sickle cell disease using dried blood specimens on blotters used for newborn screening. Hum. Genet. 81: 363-366.

Li, H., Gyllensten, U.B., Cui, X., Saiki, R.K., Erlich, H.A. and Arnheim, N. 1988. Amplification and analysis of DNA sequences in single human sperm and diploid cells. Nature 335: 414417.

Maniatis, T., Fritsch, E.F. and Sambrook, J. 1982. In Molecular Cloning: A Laboratory Manual, Cold Spring Harbor Laboratory, Cold Spring Harbor, New York, pp. 149-186.

Matsumoto, T., Kondoh, T., Yoshimoto, M., Fujieda, K., Matsuura, N., Matsuda, I., Miike, T., Yano, K., Okuno, A., Aoki, Y., Murano, I., Toyota, S., Ohnishi, S. and Niikawa, N. 1988. Complex glycerol kinase deficiency: Molecular-genetic, cytogenetic, and clinical genetic studies of five Japanese patients. Am. J. Med. Genet. 31: 602-616.

McCabe, E.R.B., Huang, S.-Z., Selzer, W.K. and Law, M.L. 1987. DNA microextraction from dried blood spots on filter paper blotters: Potential applications to newborn screening. Hum. Genet. 75: 213-216.

Southern, E. 1975. Detection of specific sequences among DNA fragments separated by gel electrophoresis. J. Mol. Biol. 98: 503-517. 